\title{
DIGITALCOMMONS
}

@WAYNESTATE -

Wayne State University

$1-1-2007$

\section{Marrying Diversity and Independence in the Boardroom: Just How Far Have You Come, Baby?}

Erica Beecher-Monas

Wayne State University

\section{Recommended Citation}

Beecher-Monas, Erica. Marrying Diversity and Independence in the Boardroom: Just How Far Have You Come, Baby?. 86 Or. L. Rev. $373,412(2007)$

Available at: https://digitalcommons.wayne.edu/lawfrp/332 


\section{Marrying Diversity and Independence in the Boardroom: Just How Far Have You Come, Baby?}

$\mathrm{Y}$ ears after the Sarbanes-Oxley ("SOX") corporate governance reform was supposed to solve the problems of director dereliction that resulted in the Enron/WorldCom string of scandals, spectacles of corporate greed continue. Corporate directors - the supposed guardians of shareholders' interests-supinely have approved untoward levels of executive pay, ${ }^{2}$ sky-high severance payments, ${ }^{3}$ stock option backdating, ${ }^{4}$

* Professor of Law, Wayne State University Law School. Many thanks go to the participants at the Law \& Society Association and Southeast Association of Law School Conferences and to Bethany Berger, Derek Bambauer, Steven Davidoff, and to participants at the Wayne State faculty forum for their comments on earlier drafts of this Article, as well as to my research assistant, Mila Cobanov.

1 Sarbanes-Oxley Act of 2002, Pub. L. No. 107-204, 116 Stat. 745 (codified as amended in scattered sections of $11,15,28$, and 29 U.S.C.) [hereinafter SOX]. For an overview and analysis of SOX, see generally Lawrence A. Cunningham, The Sarbanes-Oxley Yawn: Heavy Rhetoric, Light Reform (And It Just Might Work), 35 CONN. L. REV. 915 (2003).

2 See, e.g., In re Viacom Inc. S'holder Derivative Litig., No. 60527/05, 2006 N.Y. Misc. Lexis 2891 , at $* 24$ (N.Y. Sup. Ct. June 23,2006 ) (declining to dismiss shareholder claims that directors breached their fiduciary duty in approving $\$ 160$ million in compensation to three executives at a time when the company faced a $\$ 17.5$ billion loss).

${ }^{3}$ See, e.g., In re Walt Disney Co. Derivative Litig., 906 A.2d 27, 35-36 (Del. 2006) (exonerating Disney directors from liability despite the directors' approval of a compensation package for Michael Ovitz that included severance pay of about $\$ 130$ million although he worked at Disney only fourteen months).

${ }^{4}$ See, e.g., Press Release, U.S. Sec. \& Exch. Comm'n, SEC Charges Former Comverse Technology, Inc. CEO, CFO, and General Counsel in Stock Option 
unseemly pension payments to retired executives, ${ }^{5}$ and bonuses to retired $\mathrm{CEOs}^{6}$ and directors, ${ }^{7}$ all at shareholder expense.

Although people have been absconding with other people's money from the dawn of business history, when the best corporate citizens-large, publicly held corporations that tout their adoption of corporate best practices-fail amid scandal, it is bound to create a regulatory ripple. Indeed, the spectacle of boards of directors asleep at the wheels of governance jarred Congress into action in the wake of the multibillion-dollar Enron/WorldCom debacles and the ensuing market downturn. ${ }^{8}$ Congress responded by enacting SOX, setting out a plethora of new rules that required, among other things, the increased independence of directors. ${ }^{9}$ As a result of the emphasis on director independence, large public firms in the United States now have only one or two insiders on their boards. ${ }^{10}$ Moreover,

Backdating Scheme (Aug. 9, 2006), available at http://www.sec.gov/ news/press/2006/2006-137.htm (announcing civil charges for backdating stock option grants against directors and executives at Comverse Technology, Inc.); Press Release, U.S. Sec. \& Exch. Comm'n, U.S. Attorney's Office and SEC Separately Charge Former Brocade CEO and Vice President in Stock Option Backdating Scheme (July 20, 2006), available at http://www.sec.gov/news/press/2006/2006121.htm (announcing civil and criminal actions against Brocade Communications Systems for backdating stock option grants and falsifying corporate documents).

5 See generally Lucian A. Bebchuk \& Robert J. Jackson, Jr., Executive Pensions, 30 J. CORP. L. 823 (2005) (detailing abuses and proposing solutions).

6 See, e.g., Franklin A. Gevurtz, Disney in a Comparative Light, 55 AM. J. COMP. L. 453, 453 (2007) (discussing the bonus payment to outgoing Mannesman CEO).

7 See, e.g., Peter Klinger, Lonmin Gets 'Red Top' Alert over $£ 500,000$ Bonus, TIMES (London), Jan. 22, 2005, at 64 (discretionary payment to a retired director).

8 See Joel Seligman, THE TRANSFormation OF WALl STREet 623-24 (3d ed. 2003) (discussing the multibillion-dollar financial scandals in the period, including not only Enron and WorldCom, but Global Crossing, Tyco, and Adelphia, and remarking that the number of earnings restatements nearly tripled between 1997 and 2001). These were not merely isolated incidents, but a pattern of events that deserve analysis. See Cynthia A. Williams, Icarus on Steroids, 94 GEO. L.J. 1197, 1199 n.19 (2006) (book review) (contending that Enron was "part of a pattern of successful companies that went bankrupt or had major accounting restatements during 2001-02, and continuing").

9 See Roberta Romano, The Sarbanes-Oxley Act and the Making of Quack Corporate Governance, 114 YALE L.J. 1521, 1527-28 (2005) (noting that "SOX was emergency legislation").

10 The results of the 2006 Business Roundtable corporate-governance survey reported that " $85 \%$ of . . . company boards are composed of at least $80 \%$ independent directors." Empowering Shareholders on Executive Compensation: Hearing on H.R. 1257, the Shareholder Vote on Executive Compensation Act Before the H. Comm. on Fin. Servs., 110th Cong. 12 (2007) (statement of John J. Castellani, 
the New York Stock Exchange ("NYSE") requires three key committees-the audit, nominating, and compensation committees-to have solely independent directors. ${ }^{11}$ The European Union ("EU") also increasingly has focused on independence in corporate governance. ${ }^{12}$

Independence as the solution for director dereliction in corporate governance now appears as a mantra in government regulation, stock exchange listing requirements, corporate bestpractice standards, and legal commentary. ${ }^{13}$ The premise underlying this push for independence is that independent directors are supposed to be better monitors because, in theory at least, they will be less willing to rubber stamp management policies and more willing to consider alternative courses of action. Thus, independent boards are supposed to improve corporate governance by improving the decisions boards make.

Curiously, however, the independence standards proposed by regulators, rule makers, and commentators would not have averted the Enron/WorldCom string of scandals. Enron, for example, already met corporate best standards for director independence, and that did not stop the board from falling asleep at the wheel. ${ }^{14}$ Nor have the SOX reforms prevented subsequent scandals in corporate governance.

President, Business Roundtable). In 2004, only $9 \%$ of boards reported three insider members. Jeffrey N. Gordon, Independent Directors and Stock Market Prices: The New Corporate Governance Paradigm 14 (Columbia Law \& Econ., Working Paper No. 301, 2006), available at http://papers.ssrn.com/sol3/papers.cfm?abstract_id= 928100 (noting that "under the influence of Sarbanes-Oxley and the stock exchange listing rules, the shift [to independent directors] is virtually complete").

11 See NYSE, Inc., Listed Company Manual $\$ \S 303 \mathrm{~A} .03, .05, .06$ (2006) [hereinafter NYSE Manual]. Other exchanges have promulgated equivalent independence requirements. See, e.g., NASDAQ, Inc., Marketplace Rules 4200(a)(14)-(15), IM-4200, 4350(c)-(d), IM-4350-4 (2006) [hereinafter NASDAQ Rules].

12 See, e.g., COMM'N OF THE EUROPEAN CMTYS., COMMUNICATION FROM THE COMMISSION TO THE COUNCIL AND THE EUROPEAN PARLIAMENT: MODERNISING COMPANY LAW AND ENHANCING CORPORATE GOVERNANCE IN THE EUROPEAN UNION-A PLAN TO MOVE FORWARD 15-16 (2003).

13 See, e.g., SOX, supra note 1, §§ 101-03; NASDAQ Rules, supra note 11, 4350(c); NYSE Manual, supra note 11, §§ 303A.02-.03; PAUL W. MACAVOY \& IRA M. Millstein, THE ReCURRENT CRISIS IN CORPORATE GOVERNANCE 22-23 (2003) (arguing that case law suggests the role of directors in the corporation should be to act "independently of management, through a thoughtful and diligent decision-making process").

14 Although the new standards for director independence offer a stricter and more comprehensive definition of independence than the prior standards, they still 
This Article argues that corporate-governance reform, such as SOX, that focuses on director independence is short sighted. Independence defined as an absence of conflicting interests does not go far enough. Because directors function as a small social network, the dynamics of group decision making mean that boards need independent thought. Nourishing a culture of dissent will go farther in promoting the kind of monitoring that corporate governance is supposed to achieve. Corporate governance should aim for active, open-minded thinking on the part of directors faced with important decisions, like hiring and firing of the chief executive, setting executive pay, granting stock options, and approving conflict-of-interest transactions.

And this is where diversity comes in. Corporate-governance reform, with its focus on agency costs, and corporate diversity, with its emphasis on social equity, would appear to have little common ground. Both strands of reform, however, share an important goal: improved functioning of the corporation through more active decision making by its board. Together, director independence and diversity can produce more effective boards, with increased access to, and better analysis of, information.

Although diversity is becoming an international concern, ideas about what "diversity" means, and how to achieve it, vary greatly. On both sides of the Atlantic, diversity is taken to mean gender and ethnic diversity. This Article argues that, more broadly, diversity should mean diversity in perspectives, ideas, and experience. Diversity of thought, this Article contends, yields what independence rules are designed to achieve: better monitoring.

Better monitoring does not appear to be the reason that business leaders at home and abroad tout the benefits of diverse boards. Some reasons CEOs have given for increasing diversity are that an increasingly diverse customer base demands a broader perspective from the firm's board; diverse boards send a positive message to investors, employees, and the public; and

focus on financial ties and say nothing about the close social ties between directors and management. See, e.g., Developments in the Law, Corporations and Society, 117 HARV. L. REV. 2169, 2194-2204 (2004) (summarizing the SEC, NYSE, and NASDAQ rules, and discussing the pros and cons of the new independence standards promulgated in the wake of the Enron/WorldCom scandals and the limitations the new standards impose on business and financial ties). 
diversity is good for stock value. ${ }^{15}$ Despite touting these ideals, however, boards of directors in the United States and EU are not very diverse places. For example, Enron's board had little diversity: out of fourteen board members, there was only one woman (who was also Asian) and one African American. ${ }^{16}$

This Article argues that diverse boards are more likely to achieve the kind of active, critical thinking that independence rules are designed to achieve. To effectuate monitoring and improve corporate governance, independence must go beyond the absence of financial conflict to encompass independence of mind, diversity in viewpoint, and active discussion of alternative factual inferences and plans of action. These results are more likely - though by no means guaranteed -if the board is made up of people from diverse backgrounds and experiences.

Part I of this Article examines the theoretical and empirical bases for independence as a solution to director dereliction of monitoring duties. Part II posits that the lack of empirical support for independence as a solution to director dereliction may be due to a definitional quandary, and that defining independence as the mere absence of financial conflicts rather than as diversity of opinion may be the root of the problem. Part II turns to cognitive psychology and argues that diverse perspectives encourage better decision making. While gender and ethnic diversity are not guarantors of diversity of perspective, there are good reasons to believe that encouraging diversity will also encourage a culture of dissent, and thus improve decision making.

Part III discusses the psychology of small-group dynamics, and explains the inherent problems of group decision making in homogeneous groups. Part III suggests ways in which diversity of opinion mitigates the effects of small-group dynamics. Part IV examines the dark side of trust fostered by homogeneity, and suggests ways to overcome resistance to diversity. This Article concludes that nourishing a culture of dissent is the foundation for the kind of decision making that leads to effective

15 See Lisa M. Fairfax, The Bottom Line on Board Diversity: A Cost-Benefit Analysis of the Business Rationales for Diversity on Corporate Boards, 2005 WIS. L. REV. 795, 810-11, 854 (outlining the principal market-based or economic rationales for diversity, and concluding that "[d]iversity is an important goal in and of itself, and it may be costly to hide behind market rhetoric in order to achieve it").

16 Id. at 796 n.3. 
monitoring, and that while gender and ethnic diversity are not guarantors of diverse viewpoints, they are a good place to start in creating the kind of board culture that will take its monitoring duties seriously.

\section{THE INDEPENDENCE SOLUTION TO DIRECTOR DERELICTION}

SOX's principal solution regarding corporate governance was to emphasize the role of independent directors in the firm. ${ }^{17}$ SOX accomplished this by more strictly defining independence as the absence of financial interest, by placing independent directors on audit committees in charge of the relationship between firms and their auditors, and by putting the audit committees in charge of monitoring a system of internal accounting controls-put in place by the chief executive and chief financial officers-to ensure that the flow of information reaches the audit committees. ${ }^{18}$

Because SOX applies to foreign issuers as well as domestic ones, this regulatory response created a furor abroad, with accusations of regulatory imperialism. ${ }^{19}$ At first, the EU said

17 See, e.g., Erica Beecher-Monas, Corporate Governance in the Wake of Enron: An Examination of the Audit Committee Solution to Corporate Fraud, 55 ADMIN. L. REV. 357, 363 (2003) (discussing Sarbanes-Oxley's emphasis on the role of independent directors in monitoring the firm).

18 Under SOX, the auditor is to be hired by, and report directly to, the audit committee, which must be composed of independent directors. SOX $\S \S 204$, 301(2)-(3). At least one of those directors must be a financial expert. Id. $\S 407$. Section 407 provides that if the audit committee has no financial expert, the firm must disclose the reasons for the absence. Id. Under section 302(a), the chief executive officer and chief financial officer must certify that they have set up an internal controls system designed to ensure that material information reaches upper-level management. Id. $\S 302$ (a). The CEO and CFO also must certify that they have disclosed any deficiencies, fraud, or significant changes in the internal controls to the auditors and the audit committee. Id. This places the audit committee, with its independent directors, at the pinnacle of firm management.

${ }^{19}$ See Elizabeth Goldberg, Playing Defense Overseas: American Lawyers Crisscross the Globe as Foreign Clients Face More Scrutiny from U.S. Regulators and Law Enforcement, CORP. COUNS., Nov. 2006, at S12. Giving bite to the claims of regulatory imperialism, the SEC filed civil fraud actions against both Parmalat and Vivendi (so far resulting in a $\$ 50$ million settlement from Vivendi). Id. (noting the Parmalat settlement with the SEC); Press Release, U.S. Sec. \& Exch. Comm'n, Commission Settles Civil Fraud Action Against Vivendi Universal, S.A., Its Former CEO, Jean-Marie Messier, and Its Former CFO, Guillaume Hannezo (Dec. 23, 2003), available at http://www.sec.gov/news/press/2003-184.htm. 
U.S.-type scandals could not happen in Europe. Then along came scandals involving Vivendi (France), Ahold (Netherlands), Adecco (Switzerland), Elan (Ireland), and Parmalat (Italy), all involving financial misrepresentations missed by corporate boards. The EU Finance Ministers called for action and issued a report calling for independent directors to control audits, executive compensation, and selection of directors. ${ }^{20}$ Although the European Commission Action Plan rejected the idea of an EU corporate-governance code, advocating instead a broad framework with member flexibility and mutual recognition, ${ }^{21}$ the OECD corporate-governance principles similarly stress the importance of nonexecutive directors. ${ }^{22}$ The EU now uses a principles-based approach with companies subscribing to corporate-governance standards and disclosing areas of noncompliance. ${ }^{23}$

Whether in the United States or EU, some features of corporate governance are relatively uncontroversial. Almost universally, corporations are supposed to be managed by, or under the direction of, the board of directors. ${ }^{24}$ A key feature of the board is that it acts as a group in its decision-making processes, including its primary function of monitoring firm management. But while there has been substantial convergence on the importance of board monitoring, the structure and membership of boards vary greatly. Germany, the Netherlands, and Sweden, as well as some other EU countries, employ a two-

20 See High LeVEl Group of Co. LAW EXPERTS, European COMM'N, A MODERN REGULATORY FRAMEWORK FOR COMPANY LAW IN EUROPE 59-64 (Nov. 4, 2002), available at http://ec.europa.eu/internal_market/company/docs/ modern/report_en.pdf.

21 See Latham \& Watkins Corp. Dep't, The European Commission Publishes its Action Plan on Modernizing European Company Law \& Enhancing Corporate Governance in Response to Enron, Ahold, and the Sarbanes-Oxley Act, CLIENT ALERT (Latham \& Watkins LLP, New York, N.Y.), May 28, 2003, at 1, available at http://www.lw.com/upload/pubContent/_pdf/pub747.pdf.

22 See ORg. FOR ECON. CO-OPERATION \& DEV., OECD PRINCIPLES OF CORPORATE GOVERNANCE 25 (2004), available at http://www.oecd.org/dataoecd/ 32/18/31557724.pdf.

23 See generally id.

24 See Franklin A. Gevurtz, The European Origins and the Spread of the Corporate Board of Directors, 33 STETSON L. REV. 925, 925 (2004) (noting the convergence among nations on the use of the board of directors as the governing body for larger business organizations). 
tiered board system. $^{25}$ Employee-elected representatives, as well as shareholder-elected members, sit on the supervisory board. ${ }^{26}$ The supervisory board monitors, while the management board manages the firm. ${ }^{27}$ At first glance, this is quite a different system from the unitary board system of the United States and United Kingdom. However, in the unitary system the functions of monitoring and managing are separated by the delegation of certain critical decisions to committees of independent directors, such as the audit, compensation, and nominating committees. ${ }^{28}$

The requirement of director independence is problematic in some countries, such as Germany, where the supervisory board must by law include employees. ${ }^{29}$ Pre-SOX, audit committees were unusual in many countries. SOX's requirement that the audit committee hire, fire, and oversee the auditors is problematic in countries such as Italy and Japan, where only the shareholders may retain the auditor. ${ }^{30}$ SOX's requirement of audit committee control became quite controversial, and as a result of the controversy, the SEC created a few exemptions for

25 See, e.g., Florence Shu-Acquaye, Corporate Goverance Issues: United States and the European Union, 29 Hous. J. INT'L L. 583, 617-18 (2007) (discussing the two-tiered boards in Germany, Netherlands, Sweden, Austria, and Denmark).

26 See, e.g., Jonathan P. CHARKham, KeEPING GoOd CoMPany: A Study of Corporate Governance IN Five CounTries 17-25 (1994) (discussing the German two-tiered system).

27 Id. at 17.

28 See Klaus J. Hopt, Corporate Governance in Germany, in CAPITAL MARKETS AND COMPANY LAW 303-05 (Klaus J. Hopt \& Eddy Wymeersch eds., 2003) (discussing advantages and disadvantages of the one- and two-tiered systems).

29 See Thomas J. Andre, Jr., Some Reflections on German Corporate Governance: A Glimpse at German Supervisory Boards, 70 TUL. L. REV. 1819, 1826 (1996) (describing the German two-tiered system). This kind of two-tiered board is supposed to ensure that employee viewpoints are heard in corporate decision making. Id. It can be circumvented, however, as illustrated by the EUR 5.8 million Mannesmann settlement of criminal charges brought against the supervisory board. Derek Scally, Deutsche Bank Boss to Pay EUR 3.2m, IRISH TIMES, Nov. 25, 2006, at 19. The charges stemmed from the 2000 Vodafone acquisition of Mannesmann, which included bonus payments of EUR 56 million that had to be approved by the Mannesmann supervisory board. See Roger Boyes, Mired by Swoop from Seven Years Ago, TIMES (London), Oct. 26, 2006, at 65. The supervisory board met and approved the bonuses without the participation of the two labor representatives on the board. Id. The board only later informed the two labor representatives by telephone after the board had decided to award the bonus. See id.

30 See, e.g., Brian R. Cheffins \& Bernard S. Black, Outside Director Liability Across Countries, 84 TEX. L. REV. 1385, 1457 \& n.453 (2006) (noting that Japan's shareholders select the auditor, necessitating an exception from Sarbanes-Oxley). 
foreign issuers-primarily to accommodate the structural problems in Germany, Japan, and Italy-as long as issuers disclose their reliance on the exemption and assess whether and how their reliance on the exemption affects their ability to comply with the other regulations. ${ }^{31}$ This is an approach similar to that of a minority of EU members, which require companies to disclose and explain any failures to comply with corporate governance codes. ${ }^{32}$

Despite the protests, EU member states actually have fallen into line with SOX requirements. Two of the EU members with the largest markets, France and Germany, more or less have transplanted SOX into their own corporate-governance codes. France, in July 2003, adopted provisions similar to SOX regarding independent directors, audit committee independence, and an annual corporate-governance statement specifying how the board functions and its control procedures. ${ }^{33}$ Germany too has adopted a ten-point action plan. ${ }^{34}$ In response to the Parmalat scandal, the European Parliament adopted a resolution on corporate governance, encouraging the presence of independent directors. ${ }^{35}$ French and UK boards increased their percentage of independent board members. ${ }^{36}$ Moreover, in

31 SOX section 404 will apply to foreign filers issuing public securities in the United States; however, it is unclear how foreign filers will solve the problems of section 404 certification requirements if they have audit committees that do not comply with either voluntary codes or SOX. In the United Kingdom, for example, the Financial Services Authority adopted a Combined Code in July 2003 as an appendix to listing rules for traded companies, but no enforcement mechanisms are provided. See Thomas J. Dougherty, The Political Economy of Corporations: Varying Approaches to Corporate Governance Around the World, SL085 A.L.I.A.B.A. 253, 256 (May 2006). Rather, the expectation is that the market will reflect the investors' assessments of the departure. Id. This "comply-or-explain" regime, similar to those of other EU nations, which mainly have voluntary governance codes, may itself be influenced by the SOX requirements. See id. at 256-58 (discussing varying approaches to corporate governance and the influence SOX may have on these regimes).

32 See Dougherty, supra note 31, at 257.

33 See Luca Enriques, Bad Apples, Bad Oranges: A Comment from Old Europe on Post-Enron Corporate Governance Reforms, 38 WAKE FOREST L. REV. 911, 918-20 (2003) (discussing French legislative provisions equivalent to those of SOX).

34 See id. at 918-25.

35 European COMM'N, General REPORT ON THE ACTIVITIES OF THE EUROPEAN UNION 2004, at 21 (2005), available at http://europa.eu/generalreport/ en/rg2004.pdf.

36 See Joe Griesedieck \& Caroline Nahas, Winning the Race for Independence in the Boardroom, EXECUTIVE INSIGHT (Korn/Ferry Int'l, L.A., Cal.), 2005, at 2, 
response to the accounting scandals at Parmalat and Ahold, the EU's 8th Company Law Directive on statutory audit requires a listed company to set up an audit committee with independent members to select and oversee the auditor and auditing process. ${ }^{37}$

\section{A. What Is Independence?}

Long before the enactment of SOX, U.S. corporations had been moving toward independent boards. ${ }^{38}$ Corporate best practices recommended boards with "a majority of directors who are free of any significant relationship ... with the corporation's senior executives." 39 The definition of "significant relationship" included the firm's principal outside law firm, investment bank, and customer/supplier relationships above $\$ 200,000 .^{40}$ The NYSE listing rules now require that the independent director have "no material relationship with the listed company" as a "partner, shareholder or officer of an organization that has a relationship with the company" and address the effects of prior employment, family ties, and consulting and charitable relationships. ${ }^{41}$ In the United Kingdom, an independent director

available at http://www.kornferry.com.br/site/pdf/mediaarticles_b1047.pdf (noting that the Korn/Ferry International 2004 survey reported an average increase of one independent director on the boards of French and UK companies during 2004).

37 See Press Release, European Comm'n, Charlie McCreevy, Commissioner for Internal Market and Services, Welcomes the Agreement Reached in Council on the 8th Company Law Directive on Statutory Audit (Oct. 11, 2005), http://europa.eu/rapid/pressReleasesAction.do? reference=IP/05/1249\&format=PDF \&aged $=1 \&$ language $=\mathrm{EN} \&$ guiLanguage $=\mathrm{en}$.

38 See generally Bus. Roundtable, The Role and Composition of the Board of Directors of the Large Publicly Owned Corporation, 33 BuS. LAw. 2083, 2105-09 (1978) (arguing for independent boards).

391 AM. LAW INST., PRINCIPLES OF CORPORATE GOVERNANCE: ANALYSIS AND RECOMMENDATIONS § 3A.01 (1992) [hereinafter ALI PRINCIPLES]; see also NAT'L ASS'N OF CORP. DIRS., REPORT OF THE NACD BLUE RIBBON COMMISSION ON DIRECTOR PROFESSIONALISM 11, 31, 41 (2005).

40 See ALI PRINCIPLES, supra note $39, \S 1.34$.

41 NYSE Manual, supra note $11, \S 303$ A.00. NASDAQ has similar rules, again focused on financial ties and family relationships. See NASDAQ Rules, supra note $11,4200(a)(15)$. Independence for directors serving on the audit committee is regulated by the SEC. See, e.g., SEC Listing Standards Relating to Audit Committees, 17 CFR § 240.10A-3(b) (2007). 
must have had no business relationship with the firm for at least five years. ${ }^{42}$

Although the current standards for director independence offer a stricter and more comprehensive definition of independence than the prior standards, they still focus on financial ties and say nothing about the close social ties between directors and management. ${ }^{43}$ CEOs, even where firms have independent nominating committees, still heavily influence board selection. ${ }^{44}$ New SEC rules attempt to diminish this influence by requiring disclosure of nominating committee practices with respect to the committees' search and evaluation processes. ${ }^{45}$ However, the role of the CEO in recommending directors to the nominating committee means that many directors-independent though they may be-will be reluctant to voice dissent for fear of being asked to resign. ${ }^{46}$ Moreover, the social connections between even financially independent board members and CEOs can undermine active monitoring of the firm. ${ }^{47}$

\section{B. What Independence Is Supposed to Achieve}

The basic risk created by the separation of ownership and control is that those in control will line their pockets at the

42 Griesedieck \& Nahas, supra note 36, at 4 (citing FIN. REPORTING COUNCIL, THE COMBINED CODE ON CORPORATE GOVERNANCE (2003)).

43 See, e.g., Developments in the Law, supra note 14, at 2194-98.

44 See LuCIAN BebChuK \& JeSSE FRIED, PAY Without PERFormanCE: THE UNFULFILLED PROMISE OF EXECUTIVE COMPENSATION 80-86 (2004) (observing that the CEO, even if informally, exercises enormous power over the nominees to the board); JAY W. LORSCH WITH ElIZABETH MACIVER, PAWNS OR POTENTATES: THE REALITY OF AMERICA's CORPORATE BOARDS 20-23 (1989).

45 Disclosure Regarding Nominating Committee Functions and Communications Between Security Holders and Boards of Directors: Republication, Securities Act Release No. 8340, Exchange Act Release No. 48,825, Investment Company Act Release No. 26,262, 68 Fed. Reg. 69,204, 69,205 (Dec. 11, 2003); see also NASDAQ Rules, supra note 11, 3450(c); NYSE Manual, supra note 11, §303A.02.

46 See Eric M. Fogel et al., Public Company Shareholders Acting as Owners: Three Reforms-Introducing the "Oversight Shareholder," 29 DEL. J. CORP. L. 517, 518 (2004) (proposing more active shareholder monitoring through securing shareholder access to observe board meetings).

47 See BEBCHUK \& FRIED, supra note 44, at 25-26 (noting the pressures on board members to please the CEO, who is instrumental in the nomination process); James D. Westphal \& Edward J. Zajac, Who Shall Govern? CEO/Board Power, Demographic Similarity, and New Director Selection, 40 ADMIN. SCI. Q. 60, 77-80 (1995). 
investors' expense, diverting funds or shirking in their efforts. ${ }^{48}$ This classic agency problem can be solved, in theory at least, by monitoring the firm's managers. Monitoring may be achieved by shareholders or their representatives. Whoever does it, the effectiveness of the monitoring has repercussions not only on the individual firm and its shareholders, but on society as a whole. ${ }^{49}$ Without trust in the corporate-governance system, the economy will stagnate. It is a truism that economic growth and financial development depend on the willingness of investors to trust their funds to the management of others. ${ }^{50}$

However, monitoring is costly. Where there is a controlling shareholder block, controlling shareholders have incentives to monitor effectively. ${ }^{51}$ The downside of monitoring by controlling shareholders, however, is their ability to extract rents beyond the costs of monitoring. ${ }^{52}$ This feature of rent extraction makes it more difficult to sell minority shares. Thus, one cost of a system where large blockholders or controlling shareholders monitor, such as in the continental EU, is diminished liquidity.

At the opposite pole, widely held shareholder systems, such as those of the United States and United Kingdom, have increased liquidity but more monitoring problems. There is little incentive in such systems for shareholder monitoring. Because of collective action problems in widely held corporations,

48 See Adolph A. Berle, JR. \& Gardiner C. MEAns, The Modern CORPORATION AND PRIVATE PROPERTY 119-25 (1933) (describing the effects of separating ownership and control and discussing the ramifications of the ensuing agency problems).

${ }^{49}$ See, e.g., Ronald J. Gilson, Controlling Shareholders and Corporate Governance: Complicating the Comparative Taxonomy, 119 HARV. L. REV. 1641, 1652 (2006) (hypothesizing that the existence of a controlling shareholder serves as an alternative to independent directors and takeovers, as long as the benefits of monitoring by the shareholder exceed the extraction of rents by the controlling shareholder).

50 See Frank B. Cross \& Robert A. Prentice, Economies, Capital Markets, and Securities Law 7 (Univ. Tex. Sch. Law, Law \& Econ. Research Paper No. 73, 2006), available at http://ssrn.com/abstract $=908927$ (arguing that controlling investment risk so that investors will risk their funds has enormous economic benefits and citing studies in support).

51 See John C. Coffee, Jr., The Future as History: The Prospects for Global Convergence in Corporate Governance and Its Implications, 93 Nw. U. L. REV. 641, 648 (1999) (noting the tradeoff between concentrated ownership, with its superior monitoring, and dispersed shareholding, with its superior liquidity).

52 See id. at 648 (observing that concentrated ownership depends on hidden payments). 
shareholders have to delegate monitoring to their representatives, the board of directors. ${ }^{53}$ However, because directors initially are selected for consideration by the CEO, obtain their information about the firm from management, and generally deliberate with the CEO, directors are widely acknowledged to be co-optable by the management they are supposed to monitor. ${ }^{54}$

Independent boards are supposed to improve monitoring because, in theory at least, they will be less willing to rubber stamp management policies and more willing to consider alternative courses of action. Thus, independent boards are meant to improve corporate governance through more active board monitoring. Whether this in fact occurs is subject to considerable debate.

\section{Is Independence the Solution to Director Dereliction?}

In the United States, a string of corporate disasters in which management wrongdoing was ignored or abetted by boards precipitated the congressional action resulting in SOX. ${ }^{55}$ Both SOX and the new listing rules eventuated by market collapse are premised on the superiority of independent boards as monitors of the firm. EU corporate governance codes also stress the importance of independence of directors to corporate

53 See Lucian A. Bebchuk \& Assaf Hamdani, Federal Corporate Law: Lessons from History, 106 COLUM. L. REV. 1793, 1804 (2006) (explaining that in large, publicly held corporations, "shareholders have little incentive to exert effort to monitor management and actively intervene in corporate decisionmaking").

54 See Cross \& Prentice, supra note 50, at 11 (noting that boards of directors "plainly have failed" at the task of monitoring managers).

55 See, e.g., DENNIS R. BERESFORD ET AL., REPORT OF INVESTIGATION BY THE SPECIAL INVESTIGATIVE COMMITTEE OF THE BOARD OF DIRECTORS OF WORLDCOM, INC. 29-33 (2003), http://fl1.findlaw.com/news.findlaw.com/hdocs/ docs/worldcom/bdspcomm60903rpt.pdf (attributing WorldCom's failures to outside directors who did not understand the firm's finances, failed to notice warning signals, and were dominated by CEO Bernard "Bernie" Ebbers); WILLIAM C. POWERS, JR. ET AL., REPORT OF INVESTIGATION BY THE SPECIAL INVESTIGATIVE COMMITTEE OF THE BOARD OF DIRECTORS OF ENRON CORP. *68-75 (2002), 2002 WL 198018 (detailing the Enron board's failure to monitor its management, notice warning signals, and elicit important information); Edward S. Adams, Corporate Governance After Enron and Global Crossing: Comparative Lessons for CrossNational Improvement, 78 IND. L. J. 723, 777-78 (2003) (arguing that Global Crossing's board of directors was co-opted by its CEO). 
governance. ${ }^{56}$ But whether independent directors actually improve monitoring is questionable.

While in theory one would think that having fewer ties to management ought to foster the monitoring process, there are some nagging facts to the contrary. For instance, both Enron and WorldCom had mostly independent boards. ${ }^{58}$ Indeed, long before the advent of SOX and the new listing rules, most large, publicly held corporations already had independent boards. ${ }^{59}$ Most also had independent audit committees. ${ }^{60}$ Thus, while one might argue that a strong, independent board will pick audit committee members willing to take the auditor's side in a dispute with management, there is little evidence of this occurring in real life. ${ }^{61}$ Notably, SOX, for all its emphasis on independence and monitoring systems, would not have fixed the Enron problems; Enron had an internal compliance program, which the directors ignored, and an audit committee composed

\footnotetext{
56 See supra notes 33-37 and accompanying text.

57 See, e.g., MARGARET M. BLAIR, OWNERSHIP AND CONTROL: RETHINKING CORPORATE GOVERNANCE FOR THE TWENTY-FIRST CENTURY 80-83 (1995) (noting the lack of evidence for independence-based reforms); Stephen M. Bainbridge, A Critique of the NYSE's Director Independence Listing Standards, 30 SEC. REG. L. J. 370, 393 (2002) (noting that "empirical evidence on the merits of board independence is mixed").

58 See U.S. PERMANENT SUbCOMM. ON INVESTIGATIONS OF THE COMM. ON GOVERNMENTAL AFFAIRS, THE ROLE OF THE BOARD OF DIRECTORS IN ENRON'S COLLAPSE, S. REP. NO. 107-70, at 15 (2d Sess. 2002) [hereinafter ENRON REPORT] (describing the Enron Audit Committee Charter); RICHARD C. BREedEN, Restoring TRUST: REPORT to THE HON. JED S. RAKOFF, THE UNITED STATES DISTRICT COURT FOR THE SOUTHERN DISTRICT OF NEW YORK, ON CORPORATE GOVERNANCE FOR THE FUTURE OF MCI, INC. 30-31 (2003), available at http://www.nysd.uscourts.gov/rulings/02cv4963_082603.pdf ("At least $80 \%$ of WorldCom's directors during the Ebbers era would probably meet today's standards for director independence, as well as the standards of the time."); see also Jeffrey N. Gordon, What Enron Means for the Management and Control of the Modern Business Corporation: Some Initial Reflections, 69 U. CHI. L. REV. 1233, 1241 (2002) (noting that the Enron board was "a splendid board on paper, fourteen members, only two insiders[,] . . the outsiders had relevant business experience, ... the directors owned stock, ... [but] was ineffectual in the most fundamental way").

59 See supra note 38 and accompanying text.

60 See Romano, supra note 9, at 1575.

61 See, e.g., Jeffrey Cohen et al., The Corporate Governance Mosaic and Financial Reporting Quality, 23 J. ACCT. LITERATURE 87, 93 (2004) (asserting that "independence of audit committees may be affected by the independence of the board in general" and contending that "there is at least the potential that stronger boards in general will seek out [audit committee] members who are willing to confront management to a greater degree than previously ... documented").
} 
of outside directors (two of whom had financial expertise), and Enron was repeatedly on Fortune's list of best-managed companies. $^{62}$ Nor would SOX have fixed the problems at Parmalat: its EUR 1.5 billion in undisclosed debt (funneled into the CEO's son's soccer team and his daughter's travel business) were all missed by independent auditors, creditors, and financial analysts. $^{63}$

There is some indication that a higher percentage of outside directors decreases the occurrence of financial fraud. ${ }^{64}$ But this evidence is equivocal at best. ${ }^{65}$ Examining the relationship between corporate-governance measures and financial misstatements, Professors Anup Agrawal and Sahiba Chadha found no relation between the probability of financial restatements and either board independence, audit committee independence, or auditor conflicts. ${ }^{66}$ Agrawal and Chadha did find, however, that the probability of a restatement is

62 See Gordon, supra note 58, at 1241.

63 See Fraud (Parmalat Finanziaria): SEC Accuses Parmalat of \$100M Note Fraud, SEC v. Parmalat Finanziaria, 9 NO. 18 ANDREWS SEC. LiTIG. \& REG. REP. 8 (West Jan. 14, 2004) (describing basis for SEC enforcement action); David Reilly \& Alessandra Galloni, Top Banks Come Under Scrutiny for Role in Parmalat Scandal, WALL ST. J., Sept. 28, 2004, at A1.

64 See Mark S. Beasley et al., Fraudulent Financial Reporting: Consideration of Industry Traits and Corporate Governance Mechanisms, 14 ACCT. HORIZONS 441, 441,445 (2000) (investigating instances of financial fraud alleged by the SEC in Accounting and Auditing Enforcement Releases in three industries over the period from the late 1980s through the 1990s and concluding that "fraud companies in all three industries have less independent audit committees and less independent boards"); Joseph V. Carcello et al., CEO Involvement in Selecting Board Members and Audit Committee Effectiveness 6 (Soc. Sci. Research Network, Working Paper Series, Aug. 2006), available at http://ssrn.com/abstract=927737 (finding that independent audit committees are associated with a lower incidence of financial restatements, but noting the equivocal evidences of other researchers, and concluding that the negative association of independence and restatements does not hold when the CEO is involved in the director-selection process).

65 See, e.g., Sondra Marrakchi Chtourou et al., Corporate Governance and Earnings Management 24-26 (Soc. Sci. Research Network, Working Paper Series, Apr. 2001), available at http://papers.ssrn.com/sol3/papers.cfm?abstract_id $=275053$ (finding no significant relation between independence and the level of earnings management).

66 See Anup Agrawal \& Sahiba Chadha, Corporate Governance and Accounting Scandals, 48 J.L. \& ECON. 371,374 (2005) (analyzing 159 U.S. public corporations that restated their earnings in 2000-2001 and industry-sized matched controls of 159 nonrestating firms to conclude that while independence alone has little effect on the probability of restatement, having an independent director with financial expertise does decrease the likelihood of misstatements). 
significantly lower in companies whose boards or audit committees include an independent director with financial expertise. ${ }^{67}$ But mere accounting expertise does not appear to correlate with willingness to challenge management's position in a dispute with an auditor, although audit experience apparently does increase such support. ${ }^{68}$

There are other troubling aspects of relying on independence to remedy directors' monitoring failures. A number of recent studies report a negative correlation between the proportion of independent directors and firm performance. ${ }^{69}$ When it comes to setting CEO compensation, independent directors seem to make little difference $;^{70}$ having a high level of independence appears, counter-intuitively, to correlate with high executive compensation. ${ }^{71}$ In fact, change-in-control severance payments (known as golden parachutes) actually increase with independent boards. ${ }^{72}$ In addition, studies by Professor Mark

${ }^{67} \mathrm{Id}$. Under SOX, to qualify as a financial expert "the Commission shall consider whether a person has, through education and experience as a public accountant or auditor or a principal financial officer, comptroller, or principal accounting officer of an issuer," sufficient experience. SOX, supra note $1, \S 407$ (b). Two of the Enron audit committee's members were financial experts under this definition. Enron Corp., 2001 Proxy Proposal (Form DEF 14A), at 44-47 (Mar. 27, 2001).

68 F. Todd DeZoort \& Steven E. Salterio, The Effects of Corporate Governance Experience and Financial-Reporting and Audit Knowledge on Audit Committee Members' Judgments, 20 AUDITING 31, 43 (2001).

69 See, e.g., Sanjai Bhagat \& Bernard Black, The Non-Correlation Between Board Independence and Long-Term Firm Performance, 27 J. CORP. L. 231, 233 (2002) (noting that studies contradict conventional wisdom about the relationship between board composition and firm performance).

70 See Donald C. Langevoort, Resetting the Corporate Thermostat: Lessons from the Recent Financial Scandals About Self-Deception, Deceiving Others and the Design of Internal Controls, 93 GEO. L.J. 285, 292-95 (2004) (noting that management's ability to distort information will not be solved by the presence of independent directors on the board).

71 See Sanjai Bhagat \& Bernard Black, The Uncertain Relationship Between Board Compensation and Firm Performance, 54 BUS. LAW. 921, 930-32 (1999) (noting empirical studies suggesting that high executive remuneration is correlated with high levels of board independence). At Enron, for example, the remuneration committee appeared to believe that its function was to pay Enron executives more than those at competing firms. See ENRON REPORT, supra note 58, at 53-54.

72 See, e.g., Philip L. Cochran et al., The Composition of Boards of Directors and Incidence of Golden Parachutes, 28 ACAD. MGMT. J. 664, 667-68 (1985); Habir Singh \& Farid Harianto, Management-Board Relationships, Takeover Risk, and the Adoption of Golden Parachutes, 32 ACAD. MGMT. J. 7, 20 (1989). 
Beasley, ${ }^{73}$ among others, found that the presence of an independent audit committee does not affect the likelihood of accounting fraud. $^{74}$ This may be due to the fact that audit committees typically meet only two or three times a year, and while the board as a whole typically meets six or seven times a year, it has other issues besides financial reporting on its agenda. ${ }^{75}$ Independent directors spend relatively little time on their board duties. ${ }^{76}$ Moreover, even when the audit committee is composed solely of independent directors, management asserts a considerable influence over the quality of the interactions between the audit committee and the external auditor. $^{77}$

As for independence as a cure-all, one recent study finds that the presence of a chief financial officer ("CFO") on the board actually decreases the likelihood of financial fraud. ${ }^{78}$ Even where the majority is composed of outside directors, insiders remain a strong influence. ${ }^{79}$ This is because most of the

${ }^{73}$ See, e.g., Mark S. Beasley, An Empirical Analysis of the Relation Between the Board of Director Composition and Financial Statement Fraud, 71 ACCT. REV. 443, 443 (1996). In a study of the relationship between board composition and the likelihood of financial statement fraud, using a matched sample of fraudulent and nonfraudulent firms, Beasley reported that while nonfraudulent firms tend to have a larger proportion of outside directors than fraudulent firms, "no-fraud firms are not significantly more likely to have an audit committee, and the interaction of board composition with audit committee presence does not significantly affect the likelihood of financial statement fraud." See id. at 445; see also Cohen et al., supra note 61 , at 100 ("Surprisingly, the results [of Beasley's study] indicate that the presence of an audit committee was not associated with a reduced likelihood of financial statement fraud.").

74 See Romano, supra note 9, at 1525-33 (noting that Congress ignored evidence showing that independent directors would not solve the problem of fraudulent accounting practices).

75 See Agrawal \& Chadha, supra note 66, at 375 (explaining Beasley's findings that the audit committee composition made no difference in the incidence of fraud).

76 See BEBCHUK \& FRIED, supra note 44, at 36-37 (citing surveys showing that independent directors spend an average of 100 hours yearly on directorial duties in 2001).

77 See generally Ganesh Krishnamoorthy et al., Audit Committee Effectiveness and Financial Reporting Quality: Implications for Auditor Independence, AUSTL. ACCT. REV., Nov. 1, 2002, at $* 1-12$, available at 2002 WLNR 11692403 (survey study of audit committee effectiveness concluding that audit committees ought to play a greater role in monitoring).

78 See Bhagat \& Black, supra note 71, at 923.

79 See James P. Walsh \& James K. Seward, On the Efficiency of Internal and External Corporate Control Mechanisms, 15 ACAD. MGMT. REV. 421, 434 (1990) (citing studies showing that "there does not yet seem to be consensus support 
independent directors' information will still come, directly or indirectly, through the $\mathrm{CEO}$ and $\mathrm{CFO}{ }^{80}$ Because the independent board members normally will set the CEO's pay, the CEO has an incentive to paint a positive picture, favorably skewing information reaching them. ${ }^{81}$

Although audited financial reports ought to provide a check on management misinformation, auditors also get their information from management, and risk-management accounting means that only those items deemed high risk for the business are checked regularly outside the firm. ${ }^{82}$ Finding financial fraud is quite difficult, even for seasoned, independent auditors. ${ }^{83}$ Noting "the inherent limitations of any outside party to discover the presence of fraud," a report by the six largest accounting firms urges that periodic forensic accounting be required rather than simply relying on the quarterly or annual auditing process. ${ }^{84}$ Moreover, the willingness of audit committee

(either theoretically or empirically) for the conventional wisdom that either an increased presence of outsiders on the board of directors or the increased ownership stakes by any shareholder group (including management) necessarily improve corporate performance").

${ }^{80}$ Hence the protestations of the Enron board members that they knew nothing about the dire straits of the corporation and that management withheld key information from them. See POWERS, JR. ET AL., supra note 55, at *6.

81 See Bernard Black, The Core Institutions That Support Strong Securities Markets, 55 BUS. LAW. 1565, 1567-71 (2000) (noting that insiders will provide inaccurate information to outside directors in order to manipulate the firm's valuation).

82 See, e.g., P.W. Wolnizer, Are Audit Committees Red Herrings?, 31 ABACus 45, 51-53 (1995) (arguing that independent audit committees are unlikely to improve monitoring and noting that accounting practices permit management a great deal of discretion in choosing accounting methods and estimates, and that with the exceptions of cash and inventory, few accounting values are subject to validation through impartial evidence such as market-based data).

83 See Stefano Grazioli et al., A Cognitive Approach to Fraud Detection 4-8 (Soc. Sci. Research Network, Working Paper Series, Jan. 3, 2006), available at http://ssrn.com/abstract=920222 (noting that because of the low base rate of financial fraud, a motivated adversary, and intentional strategy, fraud detection is difficult, and setting out a heuristic to assist in the process).

84 Samuel A. Dipiazza et al., Global Capital Markets and the GLOBAL ECONOMY: A VISION FROM THE CEOS OF THE INTERNATIONAL AUDIT NETwORKS 12-13 (Nov. 2006), available at http:/www.iasb.org/NR/rdonlyres/ 727D8C0A-0507-41B4-AF3B-F505F78C9B79/0/FINALCEOVision.pdf. This report was signed by chief executives at BDO International, Deloitte \& Touche, Ernst \& Young, Grant Thornton, KPMG, and PricewaterhouseCoopers. The report proposed periodic forensic auditing; harmonizing the standards of the International Accounting Standards Board and Financial Accounting Standards 
members to challenge management in disputes with auditors is questionable. $^{85} \quad$ The Enron directors had a sophisticated compliance program, which should have funneled information to the (mostly independent) directors and the (completely independent) audit committee; the directors either ignored its requirements or ignored the information that they had obtained. ${ }^{86}$

\section{II}

\section{REDEFINING INDEPENDENCE}

Perhaps the lack of empirical support for the regulatory emphasis on director independence can be traced to a definitional quandary. Although the purpose of the independence requirement is to foster objective monitoring of the firm, the emphasis has been on director disinterest rather than on independence of thought. Disinterest has been interpreted as the absence of financial ties as well as the absence of conflict between duty and self-interest. ${ }^{87}$ There is more to independence than mere financial disinterest, however. The NYSE listing rules appear to recognize the influence of social ties and group interactions in the requirement that the independent board members meet separately to evaluate management performance and shareholder concerns. ${ }^{88}$ Separate meetings do not go far enough, however, because the members

Board based on principles; convergence of national audit standards; and minimization of national differences in the oversight of auditors and enforcement of audit standards. See id. at 7-14.

85 See generally DeZoort \& Salterio, supra note 68 (explaining that although audit experience does correlate with a director's willingness to support auditors in disputes with management, this appears to be unrelated to independence, and is not observed with other types of financial expertise).

86 See ENRON REPORT, supra note 58, at 14-15 (explaining that "[h]igh risk accounting practices, extensive undisclosed off-the-books transactions, inappropriate conflict of interest transactions, and excessive compensation plans were known to and authorized by the Board").

87 See Katherine M. Brown, Note, New Demands, Better Boards: Rethinking Director Compensation in an Era of Heightened Corporate Governance, 82 N.Y.U. L. REV. 1102, 1110 (2007) (observing that NASDAQ and the NYSE define independence as having "no material relationship" with the firm (quoting NYSE Manual, supra note $11, \S 303 \mathrm{~A} .02(\mathrm{a})))$.

88 See Note, Beyond "Independent" Directors: A Functional Approach to Board Independence, 119 HARV. L. REV. 1553, 1561-62 (2006) (arguing that objective monitoring requires more than financial disinterest). 
of relational teams, like boards of directors, develop strong internal relationships and engage with each other repeatedly. This is the kind of situation that evolutionary game theory suggests produces cooperative strategies, which may devolve into collusion. ${ }^{89}$ Even independent directors have repeat interactions not only with each other, but also with management and the other directors-a situation ripe for fostering collusion and subverting control mechanisms.

It is for this reason that the emphasis on independence rather than diversity of viewpoint is misplaced. Financial independence alone is not enough for effective monitoring, nor is it enough to abolish familial ties or those social ties that amount to indirect financial interest. ${ }^{90}$ What is needed for an effective board is a mix of people who can provide access to information, critical thinking about the information presented, active voicing of alternative courses of action, and some way of reaching consensus. That is what I mean by a culture of dissent.

Rather than mere financial disinterest, and separate meetings for discussions of sensitive issues such as executive compensation and audits, independence should mean independence of thought, and a willingness to voice dissent. Independent thinking prevents errors from being correlated, prevents group polarization skewing the decision in the same direction, and increases the likelihood that someone in the group will have new information. "The smartest groups ... are made up of people with diverse perspectives who are able to stay independent of each other." each other regularly, but usually come from the same background, social strata, and educational institutions are critical reasons to advocate diversity in the boardroom. ${ }^{92}$

89 See Erica Beecher-Monas, Enron, Epistemology, and Accountability: Regulating in a Global Economy, 37 IND. L. REV. 141, 157 (2003) (discussing implications of game theory for corporate governance); see also Kenneth $\mathrm{L}$. Bettenhausen, Five Years of Groups Research: What We Have Learned and What Needs to be Addressed, 17 J. MGMT. 345, 361-64 (1991).

90 See Developments in the Law, supra note 14, at 2198-99 (observing that even indirect financial ties, like those in the case In re Oracle Corp. Derivative Litigation, can influence monitoring).

91 JAMES SuROWIECKI, THE WISDOM OF CROWDS 41 (2004).

92 See generally Kenneth J. Arrow, Methodological Individualism and Social Knowledge, 84 AM. ECON. REV. 1 (1994) (discussing the limitations of methodological individualism). 
Remarkable strides appear to have been made in diversifying American boardrooms: about $75 \%$ of Fortune 1000 companies have at least one minority board member, and $82 \%$ have at least one woman, compared to $44 \%$ and $63 \%$, respectively, a decade ago. ${ }^{93}$ But this masks the sad fact that only $11 \%$ of corporate directors are women, and only $7 \%$ are minorities. ${ }^{94}$ In other words, the few women and minorities on boards take board positions at multiple corporations. ${ }^{95}$ Putting women and minorities on multiple boards is problematic in itself, in light of data suggesting that sitting on more than three boards impedes effective board monitoring. ${ }^{96}$ Not only are there few women and minority directors to go around, but these few directors rarely sit on the powerful audit, nominating, or executive compensation committees. ${ }^{97}$ Nonetheless, surveyed CEOs overwhelmingly say that they expect those numbers to change as boards become increasingly diverse in the next ten years. ${ }^{98}$ And this is true not only in the United States, but in the EU as well, where women comprise only $7.3 \%$ of the membership of boards of directors. ${ }^{99}$

93 See Fairfax, supra note 15, at 800 n.17 (citing KORN/FERRY INT'L, 31sT ANNUAL BOARD OF DIRECTORS STUDY 11 (2004)). Catalyst reports in its 2005 census that women held $14.7 \%$ of all Fortune 500 board seats. Press Release, Catalyst, 2005 Catalyst Census of Women Board Directors of the Fortune 500 Shows 10-Year Trend of Slow Progress and Persistent Challenges (Mar. 29, 2006),

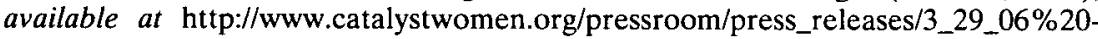
$\% 20 \mathrm{WBD} \% 20$ release.pdf (noting that at this rate, "it could take 70 years for women to reach parity with men on corporate boards"). Women of color hold only $3.4 \%$ of all Fortune 500 board seats. Id. And one in nine Fortune 500 boards has no women at all. $I d$.

${ }^{94}$ Bus. for Soc. Responsibility, Board Diversity, http://www.bsr.org/insight/issuebrief-details.cfm?DocumentID=443 (last visited Oct. 25, 2007).

95 See Fairfax, supra note 15, at 802 (noting that while only twenty-seven directors of Fortune 500 companies sit on five or more boards, seven are African Americans, and of the five directors who sit on six or more boards, four are African Americans).

96 See Lynne L. Dallas, Law and Public Policy: A Socioeconomic APPROACH 574-78 (2005).

97 Marlene A. O'Connor, Women Executives in Gladiator Corporate Cultures: The Behavioral Dynamics of Gender, Ego, and Power, 65 MD. L. REV. 465, 470 (2006) (noting that while women are less likely to serve on these powerful committees, they are more likely to serve on corporate social responsibility committees).

98 KORN/FERRY INT'L, supra note 93, at 11.

99 HeIdrick \& STRUgGles InT'L, INC., CORPORATE Governance IN EUROPE: WHAT'S THE OUTLOOK? 14 (2005), available at http://www .heidrick.com/NR/rdonlyres/B1A816CD-0E51-4605-B22C-40CB1B50561D/0/HS 
Lack of diversity remains a major concern in the EU, where $46 \%$ of European companies have no women on their boards, nor do $31 \%$ have foreign directors (foreignness apparently being the EU proxy for ethnic diversity).

That diverse boards make better decisions is not a new observation, ${ }^{101}$ but it is an important justification for reform, since corporations are managed by, or under the direction of, boards of directors. It seems intuitive that individuals with diverse perspectives and backgrounds will enlarge the scope of any discussion, considering alternatives and bringing more information to the table. ${ }^{102}$ People with different backgrounds have not only different perspectives, but varied approaches to assessing information, which should, in theory at least, lead to better decisions. For example, if the predominantly white-male CEOs of Fortune 500 companies are right about the differences in male and female traits ${ }^{103}$ (and putting aside the question of whether these stereotypes are justified), adding a female perspective only could help make more balanced decisions. Diversity of thought is important to the quality of board discussions, and this diversity of experience means that women and minorities raise new issues for board consideration based on their unique experiences. ${ }^{104}$

EuropeCorpGovOutlook.pdf (noting that while the statistics show a $22 \%$ increase in the number of women on boards, it is up from the low base of $6 \%$ in 2003).

$100 \mathrm{Id}$.

101 See, e.g., Lynne L. Dallas, The New Managerialism and Diversity on Corporate Boards of Directors, 76 TUL. L. REV. 1363, 1403-05 (2002) (concluding that diverse boards engage in better decision making); Marleen A. O'Connor, The Enron Board: The Perils of Groupthink, 71 U. CIN. L. REV. 1233, 1306-08 (2003) (contending that "diversity may enhance board effectiveness"); Steven A. Ramirez, A Flaw in the Sarbanes-Oxley Reform: Can Diversity in the Boardroom Quell Corporate Corruption?, 77 ST. JOHN'S L. REV. 837, 863 (2003) (contending that the "failure of the Sarbanes-Oxley reforms to address diversity will ultimately also hurt the ability of American business to attract capital in international markets").

102 Susan E. Jackson, Consequences of Group Composition for the Interpersonal Dynamics of Strategic Issue Processing, in 8 ADVANCES IN STRATEGIC MANAGEMENT 355-59 (Paul Shrivastava et al. eds., 1992).

103 According to these stereotypes, males are risk taking, self-confident, competitive, decisive, and direct, whereas women are empathetic, supportive, nurturing, relationship building, and power sharing. See, e.g., KORN/FERRY INT'L, supra note 93, at 11.

104 See ViCKI W. KRAMER ET AL., CRITICAL MASS ON CORPORATE BoARdS: Why THREe OR MORE WOMEN ENHANCE GOVERnANCE 8 (Wellesley Ctrs. for Women, Report No. WCW 11, 2006) (surveying men and women board members and CEOs, and finding that "[m]any respondents mentioned the importance of 
Indeed, the Canadian experience with diverse boards is revealing. A study by the Conference Board of Canada found that $94 \%$ of boards with at least three women ensured compliance with internal conflict-of-interest guidelines, while only $68 \%$ of all-male boards complied. ${ }^{105}$ Diverse boards also assumed corporate-governance responsibilities with greater frequency, which, together with numerous other examples of how diverse boards functioned, led the Canadian Report to conclude that diversity "does change the functioning and deliberative style of the board in clear and consistent ways." 106

A recent study by the Wellesley Centers for Women concludes that not only do women on the board make a difference, but the number of women matters. ${ }^{107}$ When there is only one woman on a board, her view represents "a woman's point of view," and may be disregarded by her fellow board members. ${ }^{108}$ But on boards with three or more women, the female board members are treated as individuals, with divergent points of view that can have a more substantive effect on board decision making. ${ }^{109}$ The Wellesley study found that having a critical mass of women directors enhances board decision making by changing board dynamics and raising different issues, so that difficult issues were less likely to be ignored, and the content of the discussion was more likely to include perspectives of multiple stakeholders. ${ }^{10}$ One CEO identified "more transparency with diversity . . and people express opinions in a clearer way."

diversity of thought to the quality of board discussions and linked diversity of thought to different categories of diversity, including gender, race/ethnicity, national origin, field of interest, and position").

105 DAVID A.H. BROWN ET AL., WOMEN ON BOARDS: NOT JUST THE RIGHT THING . . BUT THE "BRIGHT" ThiNG 13 (Conference Bd. of Can., May 2002), available at http://www.conferenceboard.ca/documents.asp? rnext=374.

106 Id. at ii.

107 See KRAMER ET AL., supra note 104, at iv-v (concluding that "a critical mass of three or more women can cause a fundamental change in the boardroom and enhance corporate governance").

108 Id. at 18.

109 See id. at 34.

110 See id. at 9 (finding that a majority of directors and CEOs interviewed "mentioned that women directors raise different kinds of issues than men do").

111 Id. at 8. 


\section{III}

\section{GROUP DYNAMICS}

In addition to the empirical studies that cast doubt on independence as a solution to board dereliction, cognitive psychology gives some insight into why merely removing conflict of interest may not solve the problem of director dereliction. Although market theorists have demonstrated that repeat players in the markets show what James Surowiecki terms "the wisdom of crowds," Interactive groups are especially subject to polarization effects, herding, and information cascades. Diversity in the makeup of the group should ameliorate these problems. The importance of diversity-in the sense of different life experiences, skills, and cognitive approaches-is that it adds new perspectives that would otherwise be absent and mitigates some of the effects of small-group dynamics. ${ }^{113}$

One anomalous tendency of group decisions is that groups often polarize; that is, the group will make more extreme decisions than the initial position of any individual in the group would have predicted. ${ }^{114}$ The result is that group decisions tend to coalesce around an extreme position rather than around the middle of the individually held antecedent positions. ${ }^{15}$ This is more acute when the group is homogeneous, such as within the upper echelon of corporate management, because if group members share a particular bias, polarization may magnify its impact. The tendency of directors to share the same social and educational backgrounds, ethnicity, and gender makes sharing

112 See SUROWIECKI, supra note 91, at XIV, 29-30 (noting the ease with which "a few biased individuals . . . exert undue influence and skew the group's collective decision").

113 Id. at 29-30.

114 See, e.g., Daniel J. Isenberg, Group Polarization: A Critical Review and MetaAnalysis, 50 J. PeRsonality \& SOC. PSYCHOL. 1141, 1141 (1986) (noting that group polarization occurs when "an initial tendency of individual group members toward a given direction is enhanced following group discussion"). For a discussion of group polarization in the context of audit committee deliberations, see BeecherMonas, supra note 17 , at $377-80$.

115 See Cass R. Sunstein, Deliberative Trouble? Why Groups Go to Extremes, 110 YALE L.J. 71, 85-86 (2000) (observing that " $[\mathrm{t}]$ he effect of deliberation is both to decrease variance among group members, as individual differences diminish, and also to produce convergence on a relatively more extreme point among predeliberation judgments"). 
particular biases-and therefore polarization-more likely. Because of the phenomenon of group polarization, both risk aversion and risk preference may be magnified in group decisions. ${ }^{116}$ Thus, while random errors of individuals should be cancelled out by other random errors in a group process, they are not if the errors are skewed in the same direction.

Moreover, even a small shift in the heterogeneity of the group can have a large impact on the group's behavior. ${ }^{11}$ Disagreement from even one persistent individual will force the group to discuss the issue more thoroughly than it otherwise would. ${ }^{118}$ But a lone member of a minority demographic group that historically has held less power or social status is not likely to express that dissent. ${ }^{19}$ While a second minority group member may improve this situation somewhat, three members appear to create a supportive environment that makes a real difference. ${ }^{120}$

\footnotetext{
116 See Paul E. Jones \& Peter H.M.P. Roelofsma, The Potential for Social Contextual and Group Biases in Team Decision-Making: Biases, Conditions and Psychological Mechanisms, 43 ERGONOMICS 1129, 1144 (2000) (noting that two special cases of group polarization are "risky shift," when the group becomes more risk seeking, and "cautious shift," when the group becomes more risk averse than the average tendencies of the individual members).

117 This phenomenon is often referred to as critical mass theory, originating in theories of collective behavior. See generally Mark Granovetter, Threshold Models of Collective Behavior, 83 AM. J. SOC. 1420 (1978) (describing the theory of discontinuity in social influence of a subgroup before and after a critical mass has been reached). This theory was popularized in MALCOLM GLADWELL, THE TipPing PoINT: How LitTle Things CAN MAKE A Big Difference (2000).

118 See Charlan Jeanne Nemeth, Differential Contributions of Majority and Minority Influence, 93 PSYCHOL. REV. 23, 24-25 (1986) (noting that a persistent minority view influences the group to examine its views more closely, leading to a higher-quality decision).

119 See Mischa Thompson \& Denise Sekaquaptewa, When Being Different Is Detrimental: Solo Status and the Performance of Women and Racial Minorities, 2 ANALYSES SOC. IsSUES \& PUB. POL'Y 183, 185-89 (2002) (noting token members of a demographic group are stereotyped and isolated, creating self-doubt and lowering performance).

120 KRAMER ET AL., supra note 104, at 34-36 (referencing JOHN C. TURNER WITH Michael A. HogG ET AL., Rediscovering THE Social Group: A SElFCATEGORIZATION THEORY (1987), to study the critical mass theory in the context of women directors). The Wellesley Report noted that on boards with two female board members, the women are frequently still "categorized, stereotyped, ignored and excluded," and that while "the presence of two women helps," it is still "difficult for their voices to be heard." KRAMER ET AL., supra note 104, at 32.
} 
Complex decisions, like those made by corporate boards, are not enhanced by group processes. ${ }^{121}$ Collective processes magnify systematic errors. ${ }^{122}$ While group processes do assist decision making in tasks that have a clear answer (because individual errors in assessing information tend to cancel each other out), if the solution is ambiguous, any shared biases of group members about whether and how to use information may skew the decision away from the optimal solution. ${ }^{123}$ Such shared biases are common when the group members have strong social ties. And while economic ties are prohibited by the rules on director independence, social ties are pervasive. Moreover, the effects of polarization are magnified in groups with strong social ties because such cohesive groups tend to have access to limited argument pools and suppress dissent. ${ }^{124}$

These systematic errors include phenomena such as the confirmation bias-a tendency for decision makers to seek evidence that confirms an initial judgment. ${ }^{125}$ Other biases include the egocentric biases of self-interest ${ }^{126}$ and cognitive

121 See Daniel Gigone \& Reid Hastie, Proper Analysis of the Accuracy of Group Judgments, 121 PSYCHOL. BULL. 149, 149 (1997) (explaining that group performance will be at the level of the average members).

122 See Norbert L. Kerr et al., Bias in Judgment: Comparing Individuals and Groups, 103 PSYCHOL. REV. 687, 713-14 (1996) (noting that although the law of large numbers suggests that random errors will cancel each other out in collective decisions, systematic errors will be magnified).

123 See Gigone \& Hastie, supra note 121, at 159.

124 See TURNER WITH HOGG ET AL., supra note 120, at 159-62; Dominic Abrams et al., Knowing What to Think by Knowing Who You Are: Self-Categorization and the Nature of Norm Formation, Conformity and Group Polarization, 29 BRIT. J. SOC. PSYCHOL. 97, 116-17 (1990); Russell Spears et al., De-Individuation and Group Polarization in Computer-Mediated Communication, 29 BRIT. J. SOC. PSYCHOL. 121, 130-32 (1990).

125 David M. Sanbonmatsu et al., Overestimating Causality: Attributional Effects of Confirmatory Processing, 65 J. PERSONALITY \& SOC. PSYCHOL. 892, 897-98 (1993) (describing a tendency for decision makers to seek out information that confirms their initial hypotheses).

126 The tendency to view information in a manner that will bolster one's own position has been studied in many contexts. See, e.g., Linda Babcock \& George Lowenstein, Explaining Bargaining Impasse: The Role of Self-Serving Biases, $11 \mathrm{~J}$. ECON. PERSPS. 109, 111-13, 116-17 (1997) (noting that mock-settlement participants tend to view the same materials differently depending on whether they had been assigned to role of plaintiff or defendant, and this tendency is observable even where there are real consequences, such as in salary negotiations between teachers' unions and school boards); Kimberly A. Wade-Barzoni et al., Egocentric Interpretations of Fairness in Asymmetric, Environmental Social Dilemmas: Explaining Harvesting Behavior and the Role of Communication, 67 
dissonance, ${ }^{127}$ which may also skew group decision making, particularly if the group is homogeneous. A well-documented bias of individuals is a tendency to overrate their abilities and their control over events, at least when the questions are difficult and the decision makers have no prior experience in making such decisions. ${ }^{128}$ Moreover, people tend to believe that their initial judgment is correct, and to ignore information that might call it into question. ${ }^{129}$ Cognitive dissonance theory suggests that people tend to take further actions that justify and reinforce decisions that they have already made. ${ }^{130}$ For example, gamblers

Organizational Behav. \& Hum. Decision Processes 111, 113 (1996) (finding evidence of egocentric biases in interpreting fairness in the fishing industry). For a discussion of information-selection biases in the context of communications regulation, see generally Derek E. Bambauer, Shopping Badly: Cognitive Biases, Communications, and the Fallacy of the Marketplace of Ideas, 77 U. COLO. L. REV. 649, 673-96 (2006) (discussing information-distorting biases).

127 See generally LEON FESTINGER, A THEORY OF COGNITIVE DisSONANCE (1957). Festinger's theory provoked a great deal of controversy, but the empirical basis for it appears to have survived the controversy. See, e.g., Thane S. Pittman, Motivation, in 1 THE HANDBOOK OF SOCIAL PSYCHOLOGY 557-58, 561 (Daniel T. Gilbert et al. eds., 4th ed. 1998) (detailing the controversy and concluding that "cognitive dissonance theory is resilient").

128 See Gerd Gigerenzer, The Bounded Rationality of Probabilistic Mental Models, in RATIONALITY: PSYCHOLOGICAL AND PHILOSOPHICAL PERSPECTIVES 284, 297-300 (K.I. Manktelow \& D.E. Over eds., 1993) (noting the results of two decades of research showing that test participants were overconfident when judging the correctness of their answers to difficult general-knowledge questions, and that participants' overconfidence disappeared when they were directed to assess their correctness regarding their prior experience in answering similar general-knowledge tests). One explanation for overconfidence is that people "confuse easily drawn inferences for easily remembered facts." Hart Blanton et al., Overconfidence as Dissonance Reduction, 37 J. EXPERIMENTAL SOC. PSYCHOL. 373, 374 (2001) (citing studies). However, we do not know if the kind of question domain makes a difference, or "whether there are simply some domains in which we tend to exaggerate the accuracy of our knowledge or judgment (not in others)." Robyn M. Dawes \& Matthew Mulford, The False Consensus Effect and Overconfidence: Flaws in Judgment or Flaws in How We Study Judgment?, 65 ORGANIZATIONAL BEHAV. \& HUM. DECISION PROCESSES 201, 210 (1996). Nonetheless, despite our ignorance about whether the results in the general-knowledge questions are equally applicable to the decisions directors make, if our goal is to optimize decision making, we should implement ways of minimizing such effects.

129 See Blanton et al., supra note 128, at 373 (2001) (citing studies asking people to evaluate their ability in solving laboratory problems and showing that "people think that they can solve problems that they cannot, think that they have made progress toward correct solutions when they have not, and think that they have drawn correct conclusions when they have not").

130 See FESTINGER, supra note 127, at 18-24. 
and voters are more confident after they have placed their bets or votes than they were before. ${ }^{131}$

In addition, the social environment of board deliberations may increase overconfidence, because greater overconfidence has been demonstrated in people acting within small social networks. ${ }^{132}$ These networks are characterized by having: three to fifteen members, a characteristic many boards of directors share; someone in a central, coordinating position, such as the chair-generally the CEO; and weak contact with outsiders, at least during the decision process. ${ }^{133}$

\section{A. How Polarization Affects Homogeneous Groups}

Rather than fracturing the group into opposing views, polarization is a consensual shift further in the direction of the group's initial tendency. ${ }^{134}$ For polarization to occur, there must be an initial leaning of the group in a particular direction. ${ }^{135}$ This kind of predilection is more common if the group is homogeneous. For example, when there is an underlying norm endorsing management positions, individuals attempt to signal that they share the group attitude. ${ }^{136}$ This results in a kind of competition, but since no one can be sure exactly what the

131 See Blanton et al., supra note 128 , at 374 (citing studies and arguing that "overconfidence reflects the motive to maintain a view of the self as a knowledgeable perceiver who makes sound judgments").

132 Joshua Klayman et al., Overconfidence: It Depends on How, What, and Whom You Ask, 79 Organizational Behav. \& Hum. DeCision Processes 216,243 (1999) (finding an overall bias toward overconfidence, particularly in small social networks).

133 See id.

134 James H. Liu \& Bibb Latane, Extremitization of Attitudes: Does Thought-and Discussion-Induced Polarization Cumulate?, 20 BASIC \& APPLIED SOC. PSYCHOL. 103, 103 (1998) (noting the difference between popular and social scientists' conceptions of polarization).

135 See Noah E. Friedkin, Choice Shift and Group Polarization, 64 AM. SOC. REV. 856, 856-58 (1999) (explaining the concept of group polarization in terms of a choice shift, which occurs "when, after a group's interaction on an issue, the mean final opinion of group members differs from the members' mean initial opinion ... in the opposite direction of the initial inclination of the group").

136 See RoBERT S. BARON ET AL., GROUP PROCESS, GROUP DECISION, GROUP ACTION 73-75 (1992) (discussing the process of polarization); Robert Steven Baron \& Gard Roper, Reaffirmation of Social Comparison Views of Choice Shifts: Averaging and Extremity Effects in an Autokinetic Situation, 33 J. PERSONALITY \& SOC. PSYCHOL. 521, 528-30 (1976) (hypothesizing that members strive to show adherence to group norms). 
average is, the value moves in the direction favored by the group norm. In studies where a group categorized itself as either risk taking or cautious, group decisions polarized in the risky direction by stereotypically risk-seeking groups and in the cautious direction by self-perceived cautious groups, although risky and cautious individuals tended to shift away from their individual predilection. ${ }^{137}$

Apparently, this polarization phenomenon is a function of group discussion. ${ }^{138}$ In interactive groups, rather than responding to information against their position by modifying their position or lowering their confidence, group members' interaction increases individuals' confidence in their decisions in a way that is not justified by increased accuracy. ${ }^{139}$ Instead, group members frequently fail to respond to the information presented. ${ }^{140}$ Thus, in a group with a strong predilection toward a particular result, having some group members who oppose the central tendency will not prevent polarization, although larger shifts occur in groups of like-minded people. ${ }^{141}$

One explanation for group polarization is that groups have an internal culture that prefers some values over others. ${ }^{142}$ This too is more likely if the group is homogeneous. During discussion,

137 John C. Turner et al., Referent Informational Influence and Group Polarization, 28 BRIT. J. SOC. PSYCHOL. 135, 143 (1989) (noting that "defining the shared characteristics of the group in advance will ensure that arguments/positions/members in line with the stereotype will tend to be perceived as more representative of the group as a whole and hence more persuasive and valued").

138 BARON ET AL., supra note 136, at 73 (noting the "process whereby group discussion tends to intensify group opinion, producing more extreme judgments among group members than existed before discussion").

139 See Chip Heath \& Rich Gonzalez, Interaction with Others Increases Decision Confidence but Not Decision Quality: Evidence Against Information Collection Views of Interactive Decision Making, 61 ORGANIZATIONAL BEHAV. \& HUM. DECISION PROCESSES 305, 306 (1995) (arguing that interaction does not cause people to assess the available information differently but merely to develop more coherent rationales for their choices and beliefs). Heath and Gonzalez studied interactive decision making-individual decisions made after consultation with the group-and distinguished it from group decision making on the basis that groups must reach a consensus and the "aggregation procedure may hide or distort changes in individual preferences." $I d$. at 307.

140 See id. at 305.

141 See Roger Brown, Social PSychology 222-26 (1986) (discussing studies on group polarization).

142 See Baron \& Roper, supra note 136, at 528-30. 
group members attempt to signal their adherence to these group norms, but because they do not know ahead of time the level of group adherence to the norms, the result is a competition that shifts the initial preferences to a more extreme level. ${ }^{143}$ This means that, if group members share a particular bias, group dynamics may intensify its impact. ${ }^{144}$ People wish to be perceived favorably by the group, so they adjust their expressed opinion in line with their image of the group position, an image already polarized because of its prototypical nature. ${ }^{14}$

Another explanation for the polarization effect is that the initial declaration of the individual's position was more moderate than the position the individual really held. ${ }^{146}$ During group deliberations, as the individual realizes the group position is more extreme, the individual is freed to express these more extreme views. ${ }^{147}$ In this explanation, there is not really a shift in underlying attitudes, but merely an increased willingness to express previously held views. Both this and the preceding explanation are social comparison theories, and suggest that group polarization occurs when high-status members of the group hold more extreme views than the mean. ${ }^{148}$ Thus, if the CEO has a predilection for a particular view, that may shift the group decision.

Yet another explanation for group polarization is the persuasive arguments theory. ${ }^{149}$ Here, the deciding factors are the number and persuasiveness of the arguments mustered in support of a given position. ${ }^{150}$ This theory also relies on a notion of underlying group orientation, which is more likely in

143 See Glen S. Sanders \& Robert S. Baron, Is Social Comparison Irrelevant for Producing Choice Shifts?, 13 J. EXPERIMENTAL SOC. PSYCHOL. 303, 311 (1977).

144 Id. at 304.

145 TURNER WITH HOGG ET AL., supra note 120, at 156.

146 See Isenberg, supra note 114, at 1142.

147 See id.

148 See George R. Goethals \& Mark P. Zanna, The Role of Social Comparison in Choice Shifts, 37 J. PERSONALITY \& SOC. PSYCHOL. 1469, 1474-75 (1979).

149 Eugene Burnstein \& Amiram Vinokur, What a Person Thinks upon Learning He Has Chosen Differently from Others: Nice Evidence for the PersuasiveArguments Explanation of Choice Shifts, 11 J. EXPERIMENTAL SOC. PSYCHOL. 412, 414-15 (1975) (noting that "[p]ersuasive-arguments theory . . . asserts that knowledge of others' choices has no direct consequences for subsequent revisions in choice).

150 Id. 
homogeneous groups. ${ }^{151}$ Under this theory, group polarization occurs when there is a disproportionately large number of persuasive arguments in the direction the group is leaning. ${ }^{152}$

\section{B. Cohesion and Trust}

Group behavior is even more complicated to study than individual behavior. ${ }^{153}$ One problem with group studies conducted in the laboratory is that such groups typically consist of strangers who meet in the laboratory, without past or future relationships, to perform a decision task. ${ }^{154}$ The studies fail to capture the complex dynamic interactions of people who interact as a group over time..$^{155}$ Indeed, a work group is defined as:

[M] ade up of individuals who see themselves and who are seen by others as a social entity, who are interdependent because of the tasks they perform as members of a group, who are embedded in one or more larger social systems (e.g., community, organization), and who perform tasks that affect others (such as customers or coworkers).

In the corporate board context, group dynamics include not only the need to accomplish group projects, such as monitoring management, but also the satisfaction of members' needs and the maintenance of the group as an ongoing system. ${ }^{157}$ Trust is

151 See Eugene Burnstein \& Amiram Vinokur, Persuasive Argumentation and Social Comparison as Determinants of Attitude Polarization, 13 J. EXPERIMENTAL SOC. PSYCHOL. 315, 316-18 (1977) (describing polarization as a result of informational influence).

152 Id.

153 See, e.g., David A. Kenny et al., Data Analysis in Social Psychology, in 1 THE HANDBOOK OF SOCIAL PSYCHOLOGY 234-37 (Daniel T. Gilbert et al. eds., 4th ed. 1998) (explaining the statistical problems with regard to nesting and multiple independent variables arising when researchers study small-group behavior and suggesting solutions).

154 See Richard L. Moreland et al., Back to the Future: Social Psychological Research on Groups, 30 J. EXPERIMENTAL SOC. PSYCHOL. 548-49 (1994) (assessing the state of group research).

155 See Joseph E. McGrath \& Linda Argote, Group Processes in Organizational Contexts, in BLACKWELL HANDBOOK OF SOCIAL PSYCHOLOGY: GROUP Processes 605 (Michael A. Hogg \& R. Scott Tindale eds., 2001) (noting the importance of context in the study of group behavior).

156 Richard A. Guzzo \& Marcus W. Dickson, Teams in Organizations: Recent Research on Performance and Effectiveness, 47 ANN. REV. PSYCHOL. 307, 308-09 (1996).

157 See McGrath \& Argote, supra note 155, at 608-09. 
more easily fostered in homogeneous groups. ${ }^{158}$ There is a fear that increased oversight and dissent will breed distrust between management and directors, causing management to withhold information, and making the board less effective in its monitoring and advising roles. ${ }^{159}$ Indeed, groups experience enormous pressure to maintain cohesiveness. ${ }^{160}$ Group members form an independent social entity embedded in a larger social system (e.g., an organization), whose decisions affect people outside the group, such as the managers they monitor or the shareholders for whom they are supposed to monitor. ${ }^{161}$ As a result of this pressure, even independent boards may fail to realistically assess alternative courses of action. ${ }^{162}$

Rather than making a collective decision resulting from many independent judgments, people in a small group influence each other's judgments. This makes decisions of small groups more volatile and extreme. Consensus becomes more important than dissent because dissent threatens the group's cohesion. Thus, the effects of polarization may be even greater for homogeneous boards that interact over many years.

Moreover, the initial speaker-generally the CEO-frames the discussion. ${ }^{163}$ This can be crucial for the decision-making

158 Donald C. Langevoort, Overcoming Resistance to Diversity in the Executive Suite: Grease, Grit, and the Corporate Promotion Tournament, 61 WASH. \& LEE L. REV. 1615, 1623 (2004) (discussing research studies).

159 See Developments in the Law, supra note 14, at 2200 (noting the fear that distrust will decrease cooperation between management and the board).

160 See BEBCHUK \& FRIED, supra note 44, at 32 (noting that boards experience "a strong emphasis on politeness and courtesy and an avoidance of direct conflict and confrontation" (quoting RAKESH KHURANA, SEARCHING FOR A CORPORATE SAVIOR: THE IRRATIONAL QUEST FOR CHARISMATIC CEOS 84 (2002)).

161 See McGrath \& Argote, supra note 155, at 607-08.

162 See Samuel N. Fraidin, Duty of Care Jurisprudence: Comparing Judicial Intuition and Social Psychology Research, 38 U.C. DAVIS L. REV. 1, 51-52 (2004) (observing that although trust and cohesiveness are held in high esteem, dissent is actually associated with more thorough consideration of evidence, and arguing that judges should consider evidence of dissent as correlated with careful decision making in duty of care cases).

163 Framing effects are the tendency of people to process information according to the way it was presented, rather than on its merits. When the same problem is expressed in two different ways, the same people often make radically different choices. For example, both patients and physicians reverse their decisions about treatment when the same information is presented as survival rates versus mortality rates. See ReID HASTIE \& ROBYN M. DAwES, RATIONAL ChOICE IN AN UNCERTAIN WORLD 302 (2001) (describing a decision test in which people who were informed about treatment options in terms of mortality or survival rates 
process. A meta-analysis of framing effects found that when a problem was framed in terms of gains, subjects chose the sure gain in over $60 \%$ of the studies, whereas subjects chose the risky gain in only $40 \%$ of the studies. ${ }^{164}$ When the problem was framed as losses, the results were reversed. ${ }^{165}$ Moreover, framing effects are durable; they persist even after their inconsistencies are explained to people.

However, adding pertinent social context information, that is, more relevant facts about the decision, can affect the way people respond to these effects. ${ }^{167}$ Thus, adding diverse views that may make information about social context available for discussion may improve group decision making.

And this brings us to an important caveat on the role of diversity on corporate boards: it must be true diversity. Neither race nor gender are necessarily a proxy for diversity of viewpoint. Having women and minorities on the board who mimic white male traits and attitudes will do little to achieve diversity. But people who replicate the attitudes of existing

reversed their treatment preferences depending on how the options were framed). For a discussion of the research on framing effects, see ERICA BEECHER-MONAS, EVALUATING SCIENTIFIC EVIDENCE 168-202 (2007). Framing effects also occur in social-dilemma games, such as the prisoner's dilemma, where the players are told at the outset of the game, either explicitly or implicitly, to cooperate or compete. The economic payoffs remain the same; nonetheless, players told to cooperate (or who are told they are playing a "community game") are more likely to cooperate, and players told that they are competing (or who are told that they are playing a "Wall Street game") are more likely to defect. See generally David Sally, Conversation and Cooperation in Social Dilemmas: A Meta-Analysis of Experiments from 1958 to 1992, 7 RATIONALITY \& SOC'Y 58 (1995).

164 Anton Kuhberger et al., The Effects of Framing, Reflection, Probability, and Payoff on Risk Preference in Choice Tasks, 78 ORGANIZATIONAL BEHAV. \& HUM. DECISION PROCESSES 204, 219 (1999).

$165 \mathrm{Id}$. There have been a host of empirical studies of prospect theory, both in its original and in its modified version. See George Wu et al., Decision Under Risk, in BLACKWEll HANDBOOK OF JUDGMENT AND DECISION MAKING 412-16 (Derek J. Koehler \& Nigel Harvey eds., 2004) (reviewing the literature and concluding that "a relatively clear picture of risky decision making and prospect theory has emerged" and proposing future research in mixed gambles, where there is some possibility of gain and some possibility of loss, as well as research into the role of emotion in choice).

166 See HASTIE \& DAWES, supra note 163, at 306 (explaining that people stood by their original, contradictory choice even after the inconsistency was explained to them).

167 James N. Druckman, Using Credible Advice to Overcome Framing Effects, 17 J.L. ECON. \& ORG. 62, 77 (2001) (concluding that the pervasiveness of framing effects may be overstated). 
board members are the most comfortable choices of the CEOs and other directors responsible for nominating new directors, because people tend to choose others who share social and economic backgrounds and who will fit in with the group. ${ }^{168}$ Moreover, those chosen must be perceived as able to manage white males-who still make up the vast majority of upper management-without making these white males uncomfortable. ${ }^{169}$ Trust and cohesiveness are sought-after qualities in a board.

Further, those diverse people with differing viewpoints who do manage to slip through the nominating process must be willing to voice their opinion. Without a critical mass, people tend to be uncomfortable voicing different points of view, an insight noted by the Supreme Court in Grutter v. Bollinger, upholding affirmative action at the University of Michigan Law School. ${ }^{170}$ Notably, most boards lack a critical mass of women and minorities. ${ }^{171}$

168 See Devon W. Carbado \& Mitu Gulati, The Law and Economics of Critical Race Theory, 112 YALE L.J. 1757, 1804-06 (2003) (book review) (noting bias in the way directors are selected).

169 See Langevoort, supra note 158 , at 1631 (predicting that "any diversity that is pursued will be women and minorities who mimic white male traits, including negative stereotyping of other women and minorities").

170 Grutter v. Bollinger, 539 U.S. 306, 330-33, 343 (2003) (endorsing business rationales for diversity as "real" rather than "theoretical," and noting the importance of critical mass for the voicing of different opinions).

171 Not all diversity scholars agree that critical mass is what we should be aiming for. For example, Professor Gerken argues for a system that she calls "second order" diversity, in which diversity among institutional bodies is encouraged rather than diversity within each body. See Heather K. Gerken, Second-Order Diversity, 118 HARV. L. REV. 1099, 1108 (2005) (discussing tradeoffs in defining diversity as statistically mirroring the population and in defining diversity as variation among decision-making bodies rather than within them). Whatever the benefits (and costs) to democracy of applying this concept to juries and electoral districts, Professor Gerken recognizes the importance of group dynamics and the key role that vocal dissent plays in ameliorating polarization, social cascades, and conformity. Id. at 1191-92. She argues that while ensuring the presence of dissenters in each decision-making body may improve each body's decision making, it may result in less dissent in the aggregate. Id. at 1192. Perhaps, but since we are a long way from having minorities on many boards, never mind having boards composed entirely of minorities at the helms of Fortune 500 companies, this is largely an academic debate. 


\section{The Role of Disagreement}

Two things appear to improve the performance of small groups: the active discussion of dissenting opinions, and aggregating the final decision (as in a blind vote). ${ }^{172}$ The importance of diversity-in the sense of different life experiences, skills, and cognitive approaches-is that it adds new perspectives that otherwise would be absent and that it mitigates some of the effects of small-group dynamics. ${ }^{173}$ Groups that are too much alike stagnate because they become increasingly less able to investigate alternative solutions. ${ }^{174}$

Although a group of diverse dummies cannot be expected to reach better collective decisions than a single smart expert, a group whose members possess a variety of skills, knowledge, and aptitude will outperform a small group of experts. ${ }^{175}$ Collective decisions that are achieved through disagreement and contest are superior to those achieved through consensus or compromise. ${ }^{176}$ Expressing dissent can improve the group's innovation. ${ }^{177}$ Creativity is also fostered in groups with active dissenters. ${ }^{178}$ And consideration of alternative solutions to a

172 See SUROWIECKI, supra note 91, at 189-90 (citing study by Alan S. Blinder \& John Morgan, Are Two Heads Better than One? An Experimental Analysis of Group vs. Individual Decision Making (Nat'l Bureau of Econ. Research, Working Paper No. 7909, 2000).

173 See id. at 29-30 (noting the ease with which "a few biased individuals [can] exert undue influence and skew the group's collective decision").

174 See James G. March, Exploration and Exploitation in Organizational Learning, 2 ORG. SCI. 71, 83-85 (1991) (discussing the potential gains from diversity in organizations).

175 See SUROWIECKI, supra note 91, at 30.

176 See id. at xix (noting the importance of diversity and independence in collective decision making).

177 See Carsten K.W. De Dreu \& Michael A. West, Minority Dissent and Team Innovation: The Importance of Participation in Decision Making, 86 J. APPLIED PSYCHOL. 1191, 1198 (2001) (surveying twenty-eight teams and finding that expressing dissent was associated with the frequency of improved approaches to work); Daniel P. Forbes \& Frances J. Milliken, Cognition and Corporate Governance: Understanding Boards of Directors as Strategic Decision-Making Groups, 24 ACAD. MGMT. REV. 489, 496-97 (1999) (noting that too much cohesion produces poor decisions).

178 See ANTHONy Patrick Carnevale \& Susan Carol Stone, The AMERICAN MOSAIC 60-61 (1995) (reviewing studies regarding the benefits of diversity to creative decision making); Lynn Van Dyne \& Richard Saavedra, $A$ Naturalistic Minority Influence Experiment: Effects on Divergent Thinking, Conflict and Originality in Work-Groups, 35 BRIT. J. SOC. PSYCHOL. 151, 156-63 (1996) 
problem is more likely in a group where there is active dissent. ${ }^{179}$ Moreover, where there is active disagreement among the group members before a decision is reached, more information is discussed during the decision-making process. ${ }^{180}$

Diversity is important because it prevents errors from being correlated and skewing the decision in the same direction, and because it increases the likelihood that someone in the group will have new information. ${ }^{181}$ This is a particular problem for boards of directors, who not only interact with each other regularly, but usually come from the same background, social strata, and educational institutions. ${ }^{182}$ In an information cascade, decisions are made by people following the decisions of those around them rather than relying on their own private information. Although it is normal and frequently beneficial to imitate the actions of others, and perhaps we are even genetically predisposed toward imitation, imitation can be disastrous, as evident from market bubbles. ${ }^{183}$ According to the financial commentator James Surowiecki, the problem arises from sequential decision making, and can be mitigated by simultaneous decision making. ${ }^{184}$ Procedures for "secret ballots" in director voting might increase the influence of diverse perspectives and help board members stay independent of each other (and the CEO), thus improving the quality of board decisions.

(observing that groups of students working together for ten weeks produced more creative work when the group contained dissenters).

179 See Forbes \& Milliken, supra note 177, at 494 (observing that the presence of dissenting members in the group results in the consideration of more alternatives).

180 See Felix C. Brodbeck et al., The Dissemination of Critical, Unshared Information in Decision-Making Groups: The Effects of Pre-Discussion Dissent, 32 EUR. J. SOC. PSYCHOL. 35, 51 (2002) (observing that dissenting group members are more likely to bring in new information and propose alternative solutions).

181 See SUROWIECKI, supra note 91, at 41 (noting that "the smartest groups ... are made up of people with diverse perspectives who are able to stay independent of each other").

182 See supra text accompanying note 92.

183 See, e.g., Herbert A. Simon, A Mechanism for Social Selection and Successful Altruism, 250 SCI. 1665-68 (1990) (arguing that most people do not distinguish between sensible and nonsensical imitation).

184 See SUROWIECKI, supra note 91, at 64-65 (suggesting that organizations "should have people offer their judgments simultaneously, rather than one after the other"). 


\section{THE DARK SIDE OF TRUST}

Trust increases cohesiveness, making group deliberations quicker and more harmonious. But it has a dark side. Decisions become less careful, more overconfident, and more extreme. That dark side manifests itself in the tendency of groups to reproduce themselves, hiring replicants of the members. Real diversity enhances decision making, but real diversity is still a long way off in corporate America, as well as in the EU. Despite the optimistic predictions of the increased productivity and profitability that would follow the elimination of discrimination, discrimination has not yet withered away. ${ }^{185}$ Why not? It appears that there is tension between the efficiencies of improved decision making and the productivity of a group that shares common traits and backgrounds.

Diversity threatens cohesion. This problem creates resistance to diversity. Cohesion may make work more productive, or at least faster, but it threatens good decision making. Empirical data suggest that the best performing firms are those with a culture of dissent. ${ }^{186}$ So even with diverse boards in place-still largely a pipe dream-a culture of dissent must be nourished for diversity to have an effect.

Given people's aversion to forces that destroy cohesiveness and trust, what can be done to achieve this culture of dissent? Some governments mandate diversity: Norway requires that $40 \%$ of board positions go to women. ${ }^{187}$ While such a requirement probably is not politically feasible in the United States, Professor Susan Sturm suggests that real diversity is achievable in the boardroom, as well as the workplace, by

185 See, e.g., Langevoort, supra note 158, at 1622-23 (observing that if discrimination is inefficient, "patterns of discrimination should wither away as competition forces its elimination" unless there is insufficient competition or there are "positive efficiencies to discrimination").

186 Jeffrey A. Sonnenfeld, What Makes Great Boards Great, HARV. BuS. REV., Sept. 2002, at 106, 111.

187 Charles Goldsmith, Norway Plans to Require Greater Gender Equality in Boardrooms, WALL ST. J., July 19, 2002, at A9 (plans to be implemented by 2005); Norway Enforces Gender Equality, INDEP. (London), Dec. 9, 2005, at 29 (noting that Norway requires gender balance on the boards of all publicly listed companies). 
implementing systems designed to overcome the harmful effects of the tournament structure of promotion. ${ }^{188}$

For example, at Deloitte \& Touche, a major accounting and investment banking firm, concern from the CEO about the firm's inability to keep women at higher levels despite equivalent hiring levels led to institutionalizing a process of data collection and problem solving. ${ }^{189}$ Ultimately, this process enabled Deloitte to counter what it had identified as the three major obstacles to women's retention and promotion: a maledominated culture that perpetuated stereotypes and assumptions about women; systems for advancement that worked for men but not women; and the need for a more balanced work-life approach. $^{190}$ After instituting the process, the percentage of women admitted to partnership rose and the turnover rate for female senior managers fell. ${ }^{19}$

Similarly, the successes of internal programs at Intel and Home Depot emphasized data collection, objective benchmarks for promotion, and support from the highest levels in the firm. ${ }^{192}$ This kind of initiative is important, not only for the workplace, but in achieving a diverse boardroom. Board members are frequently the CEOs of other firms.

One way to change board culture is to make sure firms are implementing systems that promote diversity rather than systems that obscure discrimination. Developing metrics and requiring disclosure of progress in diversity are first steps. Currently, firms must disclose, among other things, whether they

188 Susan Sturm, Second Generation Employment Discrimination: A Structural Approach, 101 COLUM. L. REV. 458, 459-62 (2001). The tournament structure of promotion was a concept illuminated by Professor Langevoort, who argued that there is an iterated corporate tournament for positions at the top of the corporate hierarchy, and that the tournament is won by self-confident, aggressive risk-takers, who are both loyal and opportunistic, and disinclined to "worry about relationships, commitments, or ethical distractions when there is a good reason to move on." Langevoort, supra note 158, at 1627-30. Anyone with a different point of view will slow things down, and impede the formation of trust. See id. at 1630. This is not, as Langevoort acknowledges, to suggest any inevitability in the tournament; it is obviously a social construct. Id . at 1631 . But the tournament provides the system with an automatic tilt that is gender biased, and may be extremely resistant to change. Id.

189 Sturm, supra note 188, at 492-93 (2001).

190 Id. at 494.

191 Id. at 498.

192 See id. at 519-20. 
have a nominating committee, what its charter is (if any), whether the members are independent, whether the committee has any policy with respect to consideration of candidates, and whether shareholder recommendations will be considered. Although board membership is disclosed (which generally serves to inform investors of the gender diversity, if not the racial diversity, of the board), there is no requirement to disclose efforts to achieve diversity.

Since, as the truism of managerial courses would have it, you manage what you measure, quantifying efforts toward diversity should improve accountability. More qualified women and minorities at the top of the corporate ladder should ultimately yield more diverse boards. But this may take time, and what are we to do in the meantime?

One possibility is to ensure that nominating committees engage in a process similar to the one developed by Deloitte, in which outside and inside advisors engage in an interactive system of collecting data about barriers to entry and addressing those barriers. Deloitte, for example, worked with two outside nonprofit research centers, Catalyst and the Center for Gender in Organizations, to help it analyze both gender problems in the workforce and gender problems' connection to strategic objectives and organizational performance. ${ }^{193}$ Together, the three organizations then worked interactively with management to institute systems to collect data, pool information, develop and evaluate standards, and improve accountability. ${ }^{194}$

Nominating committees charged with disclosure and data collection may also be able to increase diversity on corporate boards. As the Wellesley and Canadian studies suggest, increasing board diversity significantly to achieve a critical mass of diverse board members should bring new views and perspectives to the board, along with improved communication and better decision making. ${ }^{195}$

\section{CONCLUSION}

Apparently unrelated, the international efforts toward independence and diversity on corporate boards both

193 See id. at 526.

194 Id.

195 See supra notes $105-11$ and accompanying text. 
acknowledge that only active, open-minded thinking about the problems of the firm will improve monitoring. While absence of financial conflicts may be an obvious first step in improving board decision making, the empirical data show that independence is far from the last word in improving governance. As long as directors come from the same narrow pool of socially tied and ethnographically indistinguishable people, it will be difficult to achieve the range of experience and perception that goes into active, open-minded thinking. Nourishing a culture of dissent requires respect for differences.

In sum, the reason to nourish diversity is to achieve the better boards that independence of thought should foster. On grounds such as better decision making, increased profitability, increased creativity, and better morale, corporations around the world have articulated the need for diversity. Putting these words into practice, however, is proceeding at a glacial pace. One of the impediments to achieving diverse boards is the difficulty of resolving the tension between cohesiveness and the intellectual promise of diversity and dissent. To resolve this tension will require more than rhetoric. The business community has embraced the idea-if not yet the reality-of diversity. Understanding the importance of these goals should help corporations put into action systems that will enable boards to achieve the diversity and independence they espouse. Disclosure of steps taken toward this goal would be a valuable first step. 